\title{
Water restriction in different phenological stages and increased temperature affect cowpea production
}

\author{
Restrição hídrica em diferentes fases fenológicas e o aumento da temperatura \\ afetam a produção de feijão-caupi
}

\author{
Juliane Rafaele Alves Barros ${ }^{1} \mathbb{D}$, Miguel Julio Machado Guimarães ${ }^{2} \mathbb{D}$, Welson Lima Simões ${ }^{2} \mathbb{D}$, \\ Natoniel Franklin de Melo $^{2} \mathbb{D}$, Francislene Angelotti ${ }^{2 *} \mathbb{D}$
}

\author{
'Universidade Estadual de Feira de Santana/UEFS, Feira de Santana, BA, Brasil \\ ${ }^{2}$ Empresa Brasileira de Pesquisa Agropecuária/Embrapa, Embrapa Semiárido, Petrolina, PE, Brasil \\ *Corresponding author: francislene.angelotti@embrapa.br \\ Received in August 10, 2020 and approved in October 21, 2020
}

\begin{abstract}
Water deficit and high temperatures are abiotic factors that most limit plant growth and development. However, its effects depend on crop development stage and on stress duration and intensity. Thus, the objective of was to evaluate the development of cowpea subjected to water restriction in different phenological stages and to increase in air temperature. The experiment was conducted with the cultivar 'Carijó', in growth chambers, in a $4 \times 3 \times 2$ factorial arrangement, corresponding to levels of water availability $(25,50,75$, and 100\%,), phenological stages (vegetative, flowering and pod filling) and temperature regimes ( $\mathrm{T}^{\circ} 1: 20-26-33^{\circ} \mathrm{C}$ e $\mathrm{T}^{\circ} 2: 24.8-30.8-37.8^{\circ} \mathrm{C}$ ), respectively. Reduction of water availability in the vegetative and flowering stages caused decrease in grain production. The percentage of aborted flowers was higher in plants maintained under an increased temperature of $+4.8^{\circ} \mathrm{C}$, with consequent reduction in grain production. Higher water availability values favored shoot and root dry mass production. Increase of $4.8^{\circ} \mathrm{C}$ did not affect shoot and root dry mass but reduced water use efficiency by about $83 \%$. The highest enzymatic activities of CAT, GPX and SOD were found in plants subjected to the temperature of $+4.8^{\circ} \mathrm{C}$. Only APX showed lower enzymatic activity with increasing temperature. The cv. 'Carijó' is more sensitive to the $4.8^{\circ} \mathrm{C}$ increase in air temperature than to water deficits.
\end{abstract}

Index terms: Abiotic stress; oxidative stress; phenology; Vigna unguiculata.

\begin{abstract}
RESUMO
O déficit hídrico e as altas temperaturas são os fatores abióticos que mais restringem o crescimento e desenvolvimento das plantas. Entretanto, seus efeitos dependem da fase de desenvolvimento da cultura, da duração e da intensidade do estresse. Com isso, objetivou-se com esse trabalho, avaliar o desenvolvimento do feijão-caupi submetido à restrição hídrica em diferentes fases fenológicas e ao aumento da temperatura do ar. O experimento foi conduzido com a cultivar Carijó, em câmaras de crescimento, em arranjo fatorial de 4x3×2, sendo as disponibilidades hídricas $(25,50,75$, and $100 \%$, ) as fases fenológicas (vegetativa, floração e enchimento das vagens) e os regimes de temperatura ( $\mathrm{T}^{\circ} 1: 20-26-33^{\circ} \mathrm{C}$ e $\left.\mathrm{T}^{\circ} 2: 24.8-30.8-37.8^{\circ} \mathrm{C}\right)$, respectivamente. A redução da disponibilidade hídrica nas fases vegetativa e na floração ocasionou queda na produção de sementes. A porcentagem de flores abortadas foi maior para as plantas mantidas no regime de temperatura com um aumento de $4.8^{\circ} \mathrm{C}$, com consequentemente, redução na produção de sementes. O aumento da disponibilidade hídrica, favoreceu a produção de massa seca da parte aérea e da raiz. O aumento de $4,8^{\circ} \mathrm{C}$ não afetou o peso da massa seca da parte aérea e das raízes, porém, reduziu cerca de $83 \%$ da eficiência de uso da água pela planta. Verificou-se as maiores atividades enzimáticas da CAT GPX e SOD nas plantas submetidas ao regime de temperatura de com um aumento de $4.8^{\circ} \mathrm{C}$. Apenas a APX apresentou menor atividade enzimática com o aumento da temperatura. A cv. Carijó apresenta maior sensibilidade ao aumento de $4,8^{\circ} \mathrm{C}$ na temperatura do ar do que aos déficits hídricos.
\end{abstract}

Termos para indexação: Estresse abiótico; estresse oxidativo; fenologia; Vigna unguiculata.

\section{INTRODUCTION}

Climate change has become a challenge for food security (Gomes et al., 2019), since the increase in temperature and changes in rainfall pattern negatively affect agricultural production. In addition, future scenarios indicate that water deficit can dramatically affect plant growth and development in more than $50 \%$ of farmland by 2050, reducing crop yield worldwide (Hasanuzzaman et al., 2019). Although water deficit is the main abiotic factor 
affecting the water status of plants, the severity of this effect also depends on air temperature (Jumrani; Bhatia, 2018).

Cowpea (Vigna unguiculata L.) stands out for being a plant rich in protein and with socioeconomic importance for the semiarid regions (Melo et al., 2018). Some authors consider this legume as a species with greater tolerance to water stress compared to other crops (Ndiso et al., 2016; Merwad; Desoky; Rady, 2018). These characteristics make cowpea cultivation relevant for food security, especially in the face of global climate change (Carvalho et al., 2019). Although this crop is adapted to semiarid conditions, water deficit and high temperatures during its development cycle can have a negative impact on production (Ndiso et al., 2016). According to Karim et al. (2018), this impact will depend on the phenological stage of the crops during which this abiotic stress occurs.

In this context, understanding how cowpea plants will respond to future increments in water restriction and air temperature may contribute to a change in the way the management is carried out by producers, in order to maintain production sustainability. Some phenological stages such as flowering and pod filling are highly dependent on soil water availability (Oliveira et al., 2018). According to Bergamaschi and Bergonci (2017), the increment in temperature tends to increase the water demand of the atmosphere, leading to greater losses by evapotranspiration in the agricultural system, which can reduce water availability to plants. Thus, an important strategy for plant management will be to understand the phenological stage most sensitive to water deficit, so that this resource is used rationally and effectively.

In view of the above, studies that simulate the interaction of the abiotic stresses will be determinant for the adoption of management strategies, making it possible to determine the amount of water needed for the plant at the right time, hence optimizing the use of this resource (Silva et al., 2019). Thus, this study aimed to evaluate the development of cowpea subjected to water restriction in different phenological stages and to the increase in air temperature.

\section{MATERIAL AND METHODS}

The experiment was conducted in Fitotron-type growth chambers, with control of temperature, humidity and photoperiod, in 2019. The experimental design was carried out with the cultivar 'Carijó', which has major economic importance for the region and were seeded in pots with capacity of $7 \mathrm{~L}$, in a $4 \times 3 \times 2$ factorial arrangement, corresponding to levels of soil water availability, phenological stages and temperature regimes, respectively. Soil water availability levels were $25,50,75$, and $100 \%$, applied in the vegetative, flowering and pod filling phenological stages. Temperature regimes were: $\mathrm{T}^{\circ} 1$ : $20-26-33{ }^{\circ} \mathrm{C}\left(20^{\circ} \mathrm{C}\right.$ : from 8 p.m. to 6 a.m.; $26^{\circ} \mathrm{C}$ : from 6 a.m. to 10 a.m.; $33^{\circ} \mathrm{C}$ : from 10 a.m. to 3 p.m.; and $26^{\circ} \mathrm{C}$ : from 3 p.m. to 8 p.m.); $\mathrm{T}^{\circ} 2$ : $24.8-30.8-37.8^{\circ} \mathrm{C}\left(24.8^{\circ} \mathrm{C}\right.$ : from 8 p.m. to 6 a.m.; $30.8^{\circ} \mathrm{C}$ : from 6 a.m. to 10 a.m.; $37.8^{\circ} \mathrm{C}$ : from 10 a.m. to 3 p.m.; $30.8{ }^{\circ}$ C: from 3 p.m. to 8 p.m.), with four repetitions. The relative humidity was fixed at a value of $60 \%+-5 \%$ and the light intensity at $1500 \mu \mathrm{mol}$ $\mathrm{m}^{-2} \mathrm{~s}^{-1}$. These temperature values were determined from the minimum, average and maximum temperatures of the São Francisco Valley Sub-medium, which vary from 18-22, $25-27$ and $32-34{ }^{\circ} \mathrm{C}$, respectively. The increase of $4.8^{\circ} \mathrm{C}$ above these values was based on the future scenario for the temperature increase registered by the Intergovernmental Panel on Climate Change (Intergovernmental Panel on Climate Change - IPCC, 2013).

Irrigation management was performed with a TDR (Time Domain Reflectometry) device, TDR100 model from Campbell. For this experiment, coaxial cable probes with three rods were used. Initially, the TDR was calibrated for the soil used in the experiment, an Argissolo Vermelho-Amarelo eutrófico (Ultisol), according to Batista et al. (2016). Fertilization was performed three days before planting, according to the results of soil chemical analysis and recommendations for the crop (Cavalcanti, 2008). Irrigations were performed every two days based on the data generated by the TDR, with replacement of the evapotranspired volume of water, maintaining level of soil water availability soil corresponding to each treatment.

Prior to planting, all pots were irrigated up to their maximum water retention capacity. Irrigation management involving the experimental treatments began fifteen days after planting. The levels of soil water availability were applied in the different phenological stages, divided into three phases.

Plants of the first phase received water deficit only in the vegetative stage (after opening of the first compound leaf), ending from the production of the first flower buds.

In the second phase, plants were subjected to different levels of water availability in the flowering stage until the beginning of pod filling.

Plants of the third phase received water deficit only when pod filling began, ending with the harvest.

At the end of each phase, the days along which the plants were subjected to the different levels of water availability were quantified. 


\section{Biometric and production parameters}

In the flowering stage, the flowers of each plant were counted daily to obtain the number of aborted flowers. Grain yield was obtained by determining grain weight at 60 days after planting. This evaluation was performed from the pod maturity stage, according to Oliveira et al. (2018).

Shoot dry mass (SDM) and root dry mass (RDM) were evaluated after harvest, by cutting the stem close to the soil to separate shoots and roots. The materials were placed in paper bags and kept in an oven at $65^{\circ} \mathrm{C}$ until they reached constant weight $( \pm 72 \mathrm{~h})$. After this period, weighing was performed on a scale to obtain dry weight. The shoot: root ratio was also evaluated.

Water use efficiency $\left(\mathrm{g} \mathrm{l}^{-1}\right)$ was calculated as the ratio between grain production $(\mathrm{g})$ and the amount of water used in irrigation throughout the cycle.

\section{Determination of enzymatic activity}

For biochemical analyses, fully expanded green leaves without injuries were collected from the middle third of the plant in the different phenological stages. The samples were immediately stored in aluminum foil envelopes and immersed in liquid nitrogen $\left(\mathrm{NL}_{2}\right)$. Plant extracts were prepared using $1 \mathrm{~g}$ of plant material macerated in liquid nitrogen with addition of $0.01 \mathrm{~g}$ of polyvinylpolypyrrolidone and $3 \mathrm{~mL}$ of extraction buffer (pH 7.5) at the concentration of $100 \mathrm{mM}$ of potassium phosphate. Then, the extract was centrifuged at $15,000 \mathrm{~g}$ for 15 minutes at $4{ }^{\circ} \mathrm{C}$, and the obtained supernatant was used as crude enzymatic extract.

Catalase (CAT) activity was determined by following the decomposition of $\mathrm{H}_{2} \mathrm{O}_{2}$ for 60 seconds through spectrophotometric readings at $240 \mathrm{~nm}$, at temperature of $25{ }^{\circ} \mathrm{C}$, according to the method described by Havir and Mchale (1987). Ascorbate peroxidase (APX) activity was determined as described by Nakano and Asada (1981), by monitoring the oxidation rate of ascorbate using spectrophotometer with wavelength at $290 \mathrm{~nm}$, at $25^{\circ} \mathrm{C}$, for 60 seconds. Guaiacol peroxidase (GPX) activity was determined based on studies conducted by Cakmak and Horst (1991) by monitoring the reduction of guaiacol using spectrophotometer with wavelength at 470 $\mathrm{nm}$, at $25{ }^{\circ} \mathrm{C}$, for 60 seconds. Superoxide dismutase (SOD) activity was determined according to the methodology of Giannopolitis and Ries (1977), with spectrophotometer readings at wavelength of $560 \mathrm{~nm}$, and defining the SOD unit as the amount of enzyme needed to inhibit the photoreduction of NBT by $50 \%$.

\section{Statistical analysis}

The results were subjected to analysis of variance with application of Turkey test $(p<0.05)$, in which the significant simple effects and interactions between the sources of variation were tested. In case of significance, regression analysis was performed to evaluate the relationship between the evaluated parameters and the water availability and Tukey test was applied to compare the stages and temperature regimes, using the program SISVAR Version 5.6.

\section{RESULTS AND DISCUSSION}

The triple interaction of water availability $\mathrm{x}$ phenological stages $\mathrm{x}$ temperature was not significant for the variables production, shoot dry mass, root dry mass, ratio shoot:root and water use efficiency by cowpea. However, grain production was influenced by the interaction of water availability $\mathrm{x}$ phenological stages, and the simple effect of temperature. Shoot dry mass and root dry mass were influenced by the simple effects of water availability and temperature. The water availability and temperature influenced in an isolated way the ratio shoot:root The water use efficiency was influenced only by air temperature (Table 1).

Regarding grain production, the highest values were observed in plants maintained at 50, 75, and $100 \%$ water availability, with no difference related to water application in the different phenological stages. The reduction in water depth, with application of only $25 \%$ in the vegetative and flowering stages, reduced grain production by 63.33 and $50.76 \%$, respectively, when compared to $100 \%$ of water availability (Figure 1).

According to Silva et al. (2019), flowering is considered the most sensitive stage to water deficit for cowpea crop, causing flower drop and reduction in the number of pods per plant, thus reducing production. However, it was verified that the vegetative stage was as sensitive to water deficit as the flowering stage. This occurred because one of the factors that should be analyzed regarding the susceptibility of plants to abiotic stress is the duration of the period along which the plant was exposed to water deficit (Nemeskéri; Helyes, 2019; Ndiso et al., 2016).

As can be seen in Figure 2, the vegetative stage was the one that was exposed to hydric stress for the most days. Therefore, for the $25 \%$ water depth, the longer duration of the vegetative stage may have the same negative impact on grain production as the stress 
simulated in the flowering stage (Figure 1). It is worth pointing out that the reduction of water during flowering caused a significant reduction in grain production, about $50.76 \%$ (Figure 1). Similar results were reported by Karim et al. (2018), who found a reduction in the grain production of plants subjected to water deficit in the flowering stage.
Reduction in water availability (availability of $25 \%$ ) during the pod filling stage did not cause reduction in the production of cowpea plants (Figure 1). This can be explained by the lower water requirement in this period (Murga-Orrillo et al., 2016) and by the lower number of days along which plants were exposed in this stage (Ndiso et al., 2016) (Figure 2).

Table 1: Summary of the analysis of variance, by the mean square, for the variables: grain production (GP), shoot dry mass (SDM), root dry mass (RDM), ratio shoot:root (S:R) water use efficiency (WUE), enzymes catalase (CAT), ascorbate peroxidase (APX), guaiacol peroxidase (GPX) and superoxide dismutase (SOD) in cowpea.

\begin{tabular}{|c|c|c|c|c|c|c|c|c|c|c|}
\hline \multirow{2}{*}{$\begin{array}{l}\text { Variation } \\
\text { source }\end{array}$} & \multicolumn{9}{|c|}{ MS } & \multirow[b]{2}{*}{ SOD } \\
\hline & $\mathrm{GL}$ & GP & SDM & RDM & $\mathrm{S}: \mathrm{R}$ & WUE & CAT & APX & GPX & \\
\hline $\begin{array}{c}\text { Water } \\
\text { availability (WA) }\end{array}$ & 3 & $18.69 *$ & $110.00 * *$ & $41.67^{\star *}$ & $9.17^{*}$ & $0.036 \mathrm{~ns}$ & $63.99 * *$ & $605.40 * *$ & $2004.53^{* *}$ & $84.71^{* *}$ \\
\hline $\begin{array}{l}\text { Phenological } \\
\text { stages (PS) }\end{array}$ & 2 & $45.00 * \star$ & $17.83 \mathrm{~ns}$ & $7.77 \mathrm{~ns}$ & $6.85 \mathrm{~ns}$ & $0.09 *$ & $24.83^{* *}$ & $55481.47^{* *}$ & $6460.43^{* *}$ & 2138.50 ** \\
\hline Temperature (T) & 1 & $2288.13^{\star \star}$ & $1095.55^{* *}$ & $15.75^{*}$ & 23.01 ** & $16.09 * *$ & $79.57^{* \star}$ & $5988.35 * *$ & $1940.22 * \star$ & $2030.71 * *$ \\
\hline WA $\times$ PS & 6 & $22.89 * \star$ & $7.84 \mathrm{~ns}$ & $7.11 \mathrm{~ns}$ & $5.30 \mathrm{~ns}$ & $0.04 \mathrm{~ns}$ & $2.60^{*}$ & $857.60 * *$ & $96.47 \mathrm{~ns}$ & $315.40^{* *}$ \\
\hline WA $\times T$ & 3 & $0.27 n s$ & $2.70 \mathrm{~ns}$ & $0.57 \mathrm{~ns}$ & $0.30 \mathrm{~ns}$ & $0.06 n s$ & $19.71 * *$ & $1221.86^{* *}$ & $39.49 n s$ & $14.74 \mathrm{~ns}$ \\
\hline $\mathrm{PS} \times \mathrm{T}$ & 2 & $12.21 \mathrm{~ns}$ & $19.87 \mathrm{~ns}$ & $4.05 \mathrm{~ns}$ & $0.44 \mathrm{~ns}$ & $0.04 \mathrm{~ns}$ & $43.27^{* \star}$ & $1873.59 * *$ & $175.10 \mathrm{~ns}$ & $973.91 * *$ \\
\hline WA $\times$ PS $\times T$ & 6 & $8.79 \mathrm{~ns}$ & $26.35 n s$ & $2.60 \mathrm{~ns}$ & $1.45 \mathrm{~ns}$ & $0.004 \mathrm{~ns}$ & $4.76^{\star \star}$ & $718.47 * *$ & $495.84 * *$ & $47.33^{* *}$ \\
\hline Residue & 72 & 4.91 & 14.17 & 3.84 & 2.90 & 0.02 & 0.97 & 107.71 & 66.24 & 13.04 \\
\hline $\mathrm{CV} \%$ & & 28.87 & 21.37 & 30.82 & 54.04 & 27.82 & 15.84 & 19.533 & 13.63 & 14.95 \\
\hline
\end{tabular}

$\mathrm{DF}=$ degrees of freedom; CV = coefficient of variation; ns = not significant, $* \star$ significant at $1 \%$ probability level, * significant at $5 \%$ probability level by Tukey test.

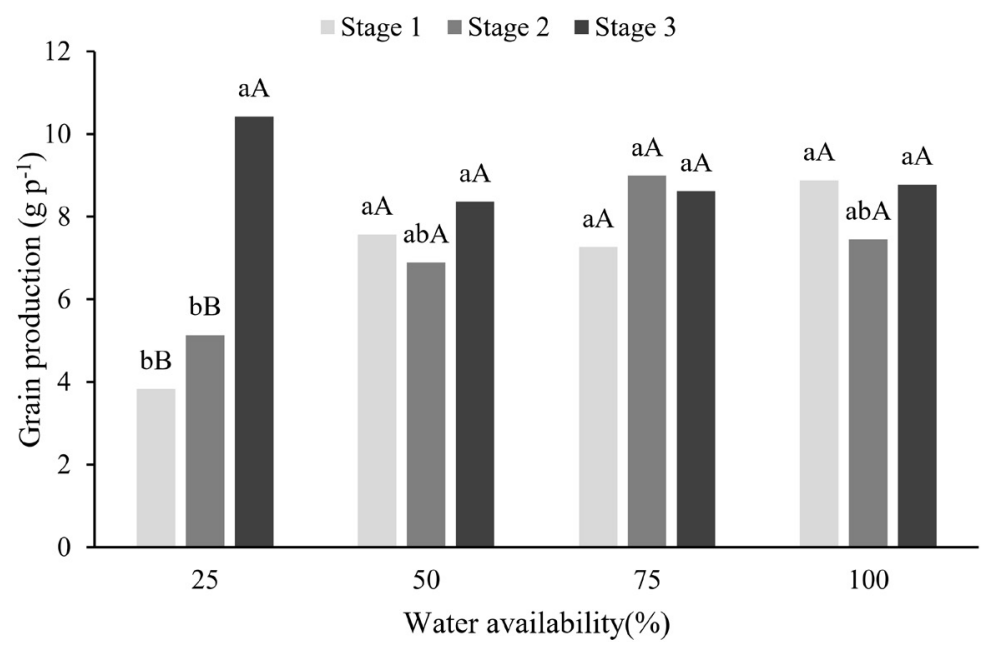

Figure 1: Mean values of grain production of cowpea plants, cultivar 'Carijó', as a function of water availability in the phenological stages (Stage 1: vegetative, Stage 2: flowering and Stage 3: pod filling). *Uppercase letters for phenological stage and lowercase letters for water availability. 


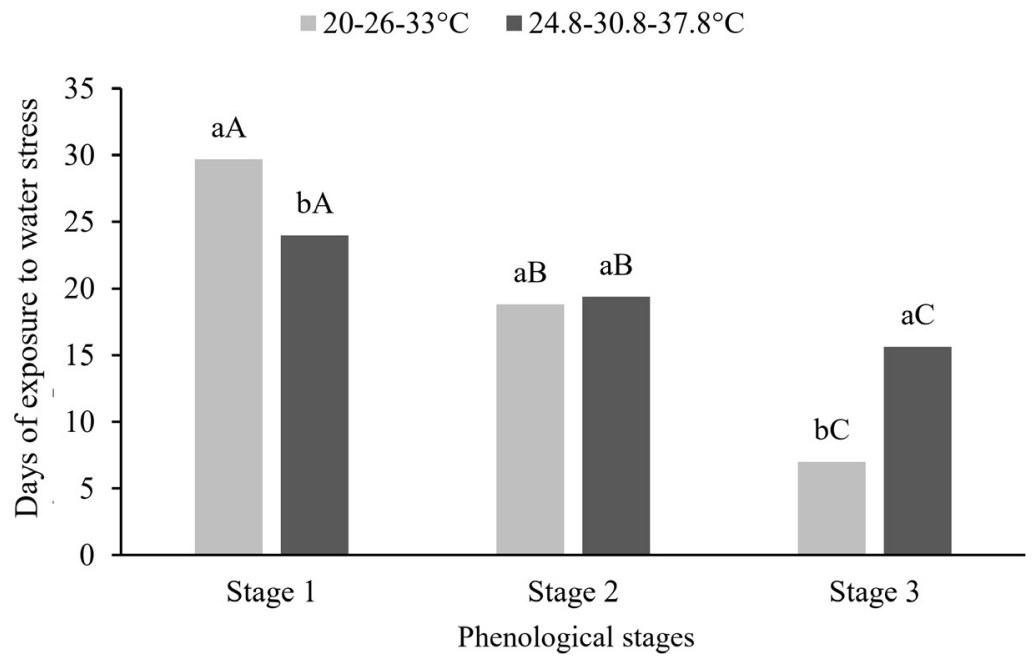

Figure 2: Mean of the days of exposure to water stress of cowpea plants, cultivar 'Carijó', as a function of temperature regime and phenological stages (Stage 1: vegetative, Stage 2: flowering and Stage 3: pod filling). *Lowercase letters for temperature and uppercase letters for phenological stage.

It can be observed that the days of exposure of plants to water stress differed with the increase in temperature in the different phenological stages (Figure 2). The vegetative stage was the longest one, with an average duration of 30 days. Thus, plants were exposed to reduction in water availability for longer. It is also observed that the increase of $4.8{ }^{\circ} \mathrm{C}$ in air temperature reduced the number of days of this stage, with reduction in the time of exposure to water stress and development cycle of the plants.

According to Bergamaschi and Bergonci (2017), the increase in temperature is associated with the acceleration of growth and phenology, so that, when subjected to stress conditions, plants alter their metabolism in order not to compromise their normal development. The acceleration of the cycle occurs because of the plant's response to the stress condition, increasing its respiration (Schmidt et al., 2017).

It is observed that the increase of $4.8^{\circ} \mathrm{C}$ in the air temperature, prolonged the exposure time of phase 3 of cowpea to water stress, due to the fall of pods. According to Hoffmann Júnior et al. (2007), high temperatures is one of the environmental factors that most influences the abscission of flowers and pods, the inadequate filling of grains and the final retention of pods in beans.

The $4.8{ }^{\circ} \mathrm{C}$ increment in air temperature caused a $79.35 \%$ increase in the percentage of aborted flowers, with a consequent reduction of $77.78 \%$ in the production of cowpea grain (Figure 3A and 3B).
Thermal stress during the reproduction of legumes causes significant loss in the yield of the grain (Hatfield; Prueger, 2015). One of the consequences is the reduction in the number of floral branches and in the number of flowers per plant (Harsant et al., 2013). Another impact is related to the low viability and germination of pollen, because the increase in temperature can affect male and female gametophytes, increasing the abortion of flowers, with consequent reduction in the number of grain (Silva et al., 2020).

In addition, high temperatures reduce grain size due to insufficient accumulation of photosynthates during the pod filling stage (Kumar et al., 2016). According to these authors, a few days of thermal stress in this stage, with temperatures between $30-35$ ${ }^{\circ} \mathrm{C}$, accelerate senescence and decrease the number and weight of grain, reducing the yield of legumes, thus corroborating the results found.

Cowpea plants of the cultivar 'Carijó' had higher water use efficiency (WUE) when grown under a temperature regime of $20-26-33{ }^{\circ} \mathrm{C}$. The $4.8{ }^{\circ} \mathrm{C}$ increase in air temperature reduced WUE by $83 \%$ (Figure $3 \mathrm{C}$ ). This behavior is a consequence of the reduction in grain production observed in plants subjected to the regime of higher temperature (Figure 3B), since this parameter represents a direct relationship between the amount of grain produced and water consumption by the plant. 

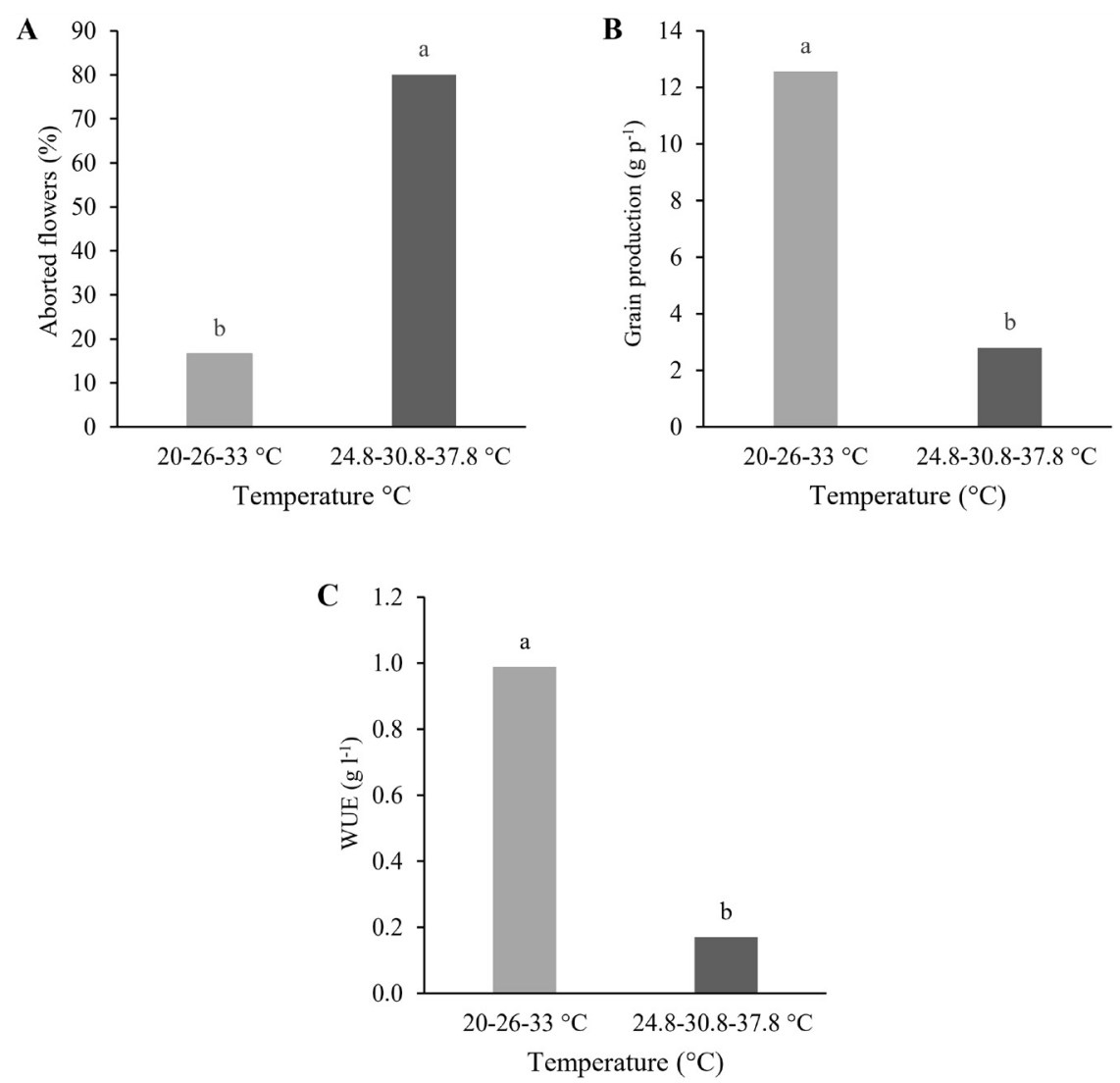

Figure 3: Mean values of percentage of aborted flowers (A), grain production (g) (B) and water use efficiency (WUE) (C) of cowpea plants, cultivar 'Carijó', as a function of temperature regimes.

The $4.8^{\circ} \mathrm{C}$ increase in air temperature resulted in an increase in shoot dry mass and root dry mass of cowpea plants (Figure 4). This can be explained by the fact that the increase in temperature results in increased vegetative development (Hatfield; Prueger, 2015). According to Sehgal et al. (2018), the leaves adapt to high temperatures because of the effective thermotolerance mechanisms, which enable the regulation of leaf temperature by transpiration during the period with high temperature (Koevosts et al., 2016). In addition, roots are more sensitive to stress due to high temperatures than the shoot plants, as indicated by the increase in the ratio of shoot:root (Figure 4C). The results are similar to those found by Giri et al. (2017), who associated this effect with greater damage caused by temperatures in plant root membranes.

The increase in water availability also had a positive effect on the dry mass of the shoot and the dry mass of the root (Figure 5). However, this effect was greater on root dry mass, as evidenced by the significant reduction in the shoot:root in Figure 5C.
Studies indicate that the biomass of legumes can be hampered by moderate and severe water deficit (Farooq et al., 2017). Plants under water deficit exhibit morphological, physiological and biochemical alterations that affect their growth, because the decrease in water availability reduces water content in plant tissues, increasing canopy temperature, with reduction in chlorophyll content and, consequently, a lower photosynthetic activity (Kumar et al., 2016; Karim et al., 2018).

For the specific activity of the evaluated enzymes, different behaviors can be observed under the temperature regimes and water availability levels evaluated in each phenological stage of the plant (Figure 6). In general, it was found that with the increase in temperature (24.8$30.8-37.8^{\circ} \mathrm{C}$ ) the highest enzymatic activities were found for CAT, GPX and SOD, while APX showed the opposite behavior in relation to the others.

The alterations in enzymatic metabolism recorded in the present study demonstrate that the stages of vegetative development and flowering have similar enzymatic 
behavior. Regarding the influence of water availability, there was a reduction in CAT activity with increased water availability in the three phenological stages evaluated, regardless of the temperature regime, except for plants subjected to low water availability in the pod filling stage (Stage 3) under the temperature regime of $20-26-33{ }^{\circ} \mathrm{C}$, for which there was no significant fit of regression (Figure 6).

The increase in CAT activity with decreasing water levels may be associated with an increase in the amount of $\mathrm{H}_{2} \mathrm{O}_{2}$ due to the thermal stress applied in the plants, as observed for wheat (Kumar et al., 2012) and mung bean (Vigna radiata L.) (Mansoor; Naqvi, 2013). However, changes in enzymatic metabolism caused by thermal stress in plants will vary according to the tolerance of the genetic material evaluated.

The activity of the APX enzyme showed different behaviors in the different stages of cowpea development. In the vegetative stage, the enzymatic activity showed opposite behaviors between temperature regimes with increasing water availability (Figure 6). While plants subjected to the temperature regime $20-26-33{ }^{\circ} \mathrm{C}$ showed

a reduction in APX activity with increasing water availability, the temperature regime of $24.8-30.8-37.8^{\circ} \mathrm{C}$, associated with the highest water availability, caused an increase in the enzymatic activity of APX.

These results highlight the effect of the interaction between the stresses applied to the APX activity. At mild temperatures the effect of stress caused by water availability is evidenced with higher enzymatic activity at low availability. In plants subjected to a $4.8^{\circ} \mathrm{C}$ increase in temperature, the combination of low water availability and high temperatures led to significant reductions in APX activity, thus demonstrating a severe stress with the combination of treatments applied. This may be related to the affinity of this enzyme with $\mathrm{H}_{2} \mathrm{O}_{2}$, which is in the micromolar order, and APX is responsible for the fine regulation of the response to environmental stresses. When the amount of $\mathrm{H}_{2} \mathrm{O}_{2}$ exceeds this order, reaching the millimolar order, which configures high oxidative stress, other enzymes come into action in the regulation of $\mathrm{H}_{2} \mathrm{O}_{2}$, such as CAT and GPX (Hasanuzzaman et al., 2012).
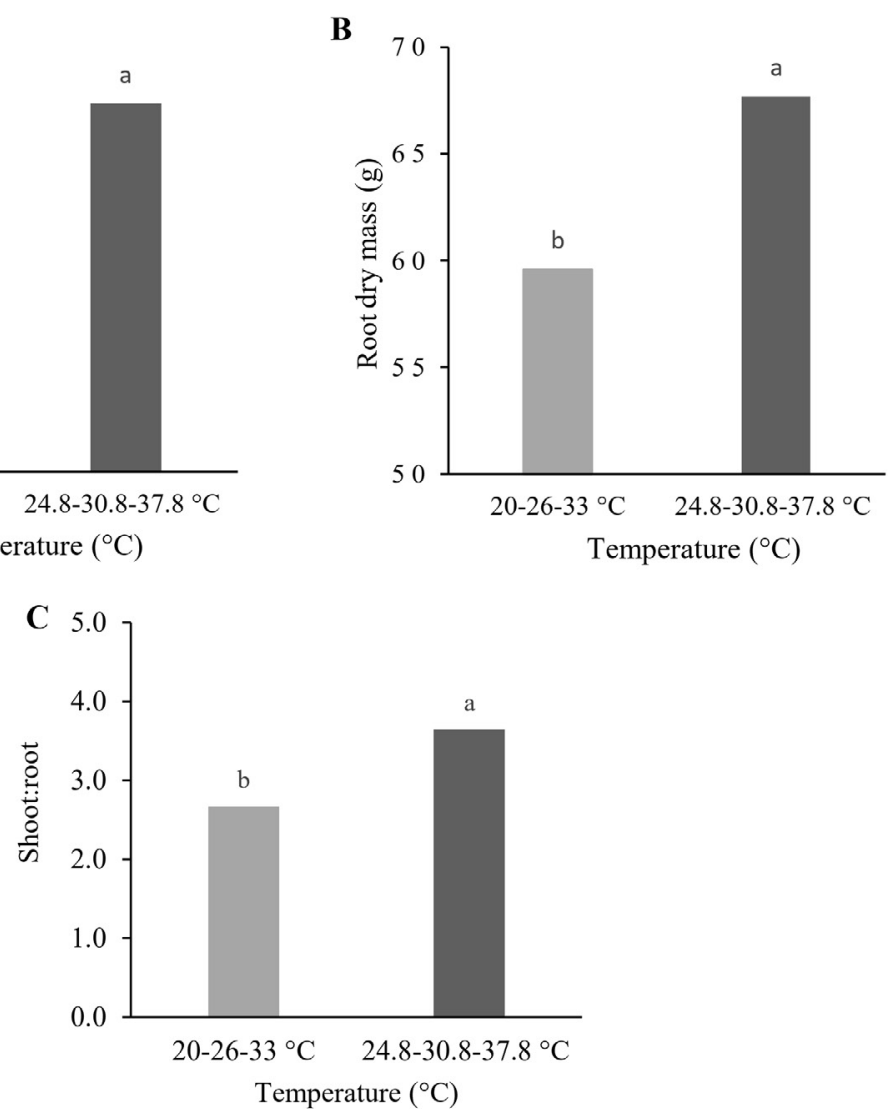

Figure 4: Mean values of Shoot dry mass (A), root dry mass (B) (g) and ratio shoot:root of cowpea plants, cultivar 'Carijó', subjected to different temperature regimes. 

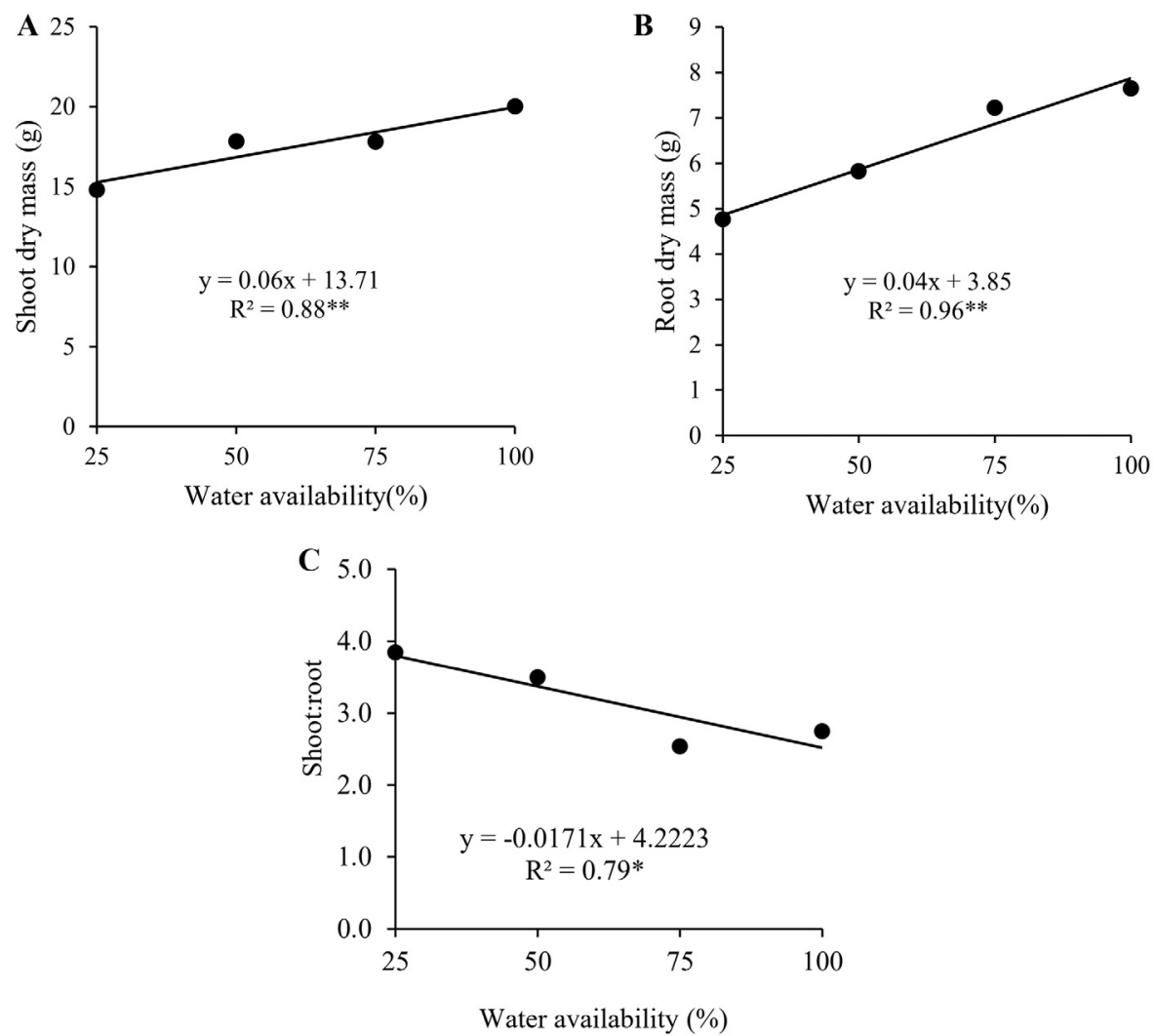

Figure 5: Shoot dry mass (A), root dry mass (B) (g) and ratio shoot:root of cowpea plants, cultivar 'Carijó', as a function of water availability. Significant regression coefficient with $p<0.05\left(^{*}\right)$ and $p<0.01(* *)$.

In the flowering stage, there was a reduction in enzymatic activity with the increase in water availability under both temperature regimes. No significant values of enzymatic activity of APX were observed in the pod filling stage. This behavior may be related to the start of the senescence stage of the plants.

The increase in water availability caused a reduction in GPX enzyme activity in all evaluated stages, except for plants subjected to the temperature regime of $20-26-33{ }^{\circ} \mathrm{C}$ in the pod filling stage (Figure 6). In this stage, there was a maintenance of the activity, regardless of the water availability level applied. Parallel to the reductions recorded, it can be observed that plants that suffered from water stress in the pod filling stage showed higher enzymatic activity of GPX. The enzymatic pattern of GPX in the evaluated plants suggests that this enzyme plays an important role in the regulation of $\mathrm{H}_{2} \mathrm{O}_{2}$ in plants subjected to water deficit, regardless of the temperature to which they are exposed. Similar results were recorded by Borella et al. (2017), who verified significant increases in GPX activity in common bean (Phaseolus vulgaris L.) cultivars when subjected to water deficit.
The enzyme SOD showed a reduction in activity with the increase in water availability in the vegetative and flowering stages (Figure 6). On the other hand, the plants subjected to different water availability levels in the pod filling stage showed an increase in the activity of this enzyme with the increase in water supply. The highest values of enzymatic activity of SOD were observed under application of a water availability level of $76.5 \%$ with 24.1(U SOD mg-1 protein) under the temperature regime of 20-26-33 ${ }^{\circ} \mathrm{C}$, and $97.2 \%$ with 47.6 (U SOD $\mathrm{mg}^{-1}$ protein) in plants subjected to a $4.8^{\circ} \mathrm{C}$ increase in air temperature.

Changes in enzymatic activities under multiple stress conditions, such as water deficit and high temperature, as observed in the present study, may be associated with the activation of oxidative defense mechanisms of plants (Mansoor; Naqvi, 2013). The higher activity of antioxidant enzymes can contribute to a better tolerance to water deficit, thus justifying greater enzymatic activities in plants subjected to water stress, such as the activity of enzymes responsible for maintaining oxidative homeostasis in cowpea (Carvalho et al., 2019). 
Stage 1
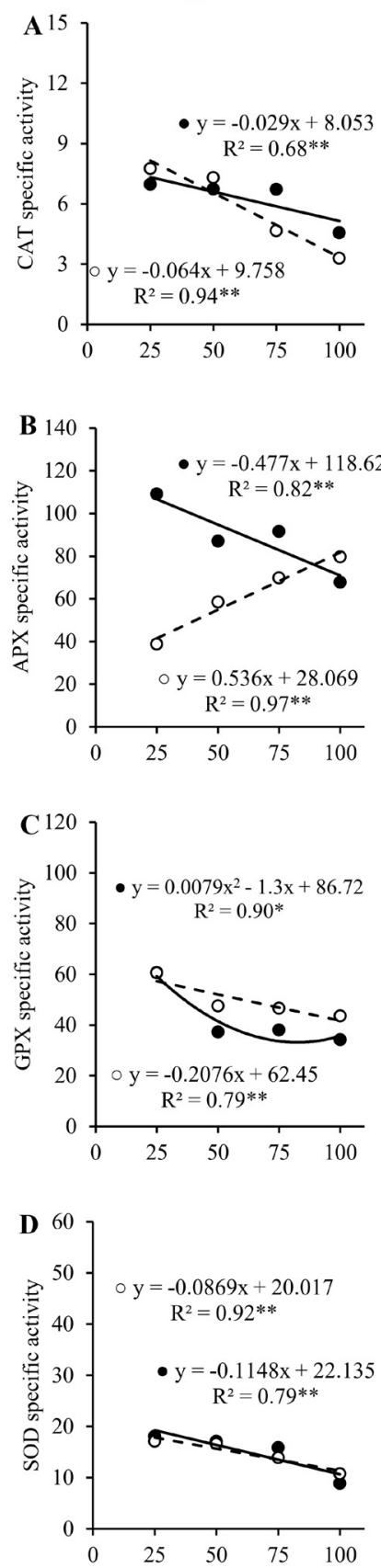

- $20-26-33^{\circ} \mathrm{C}$

Stage 2

○ $24.8-30.8-37.8^{\circ} \mathrm{C}$
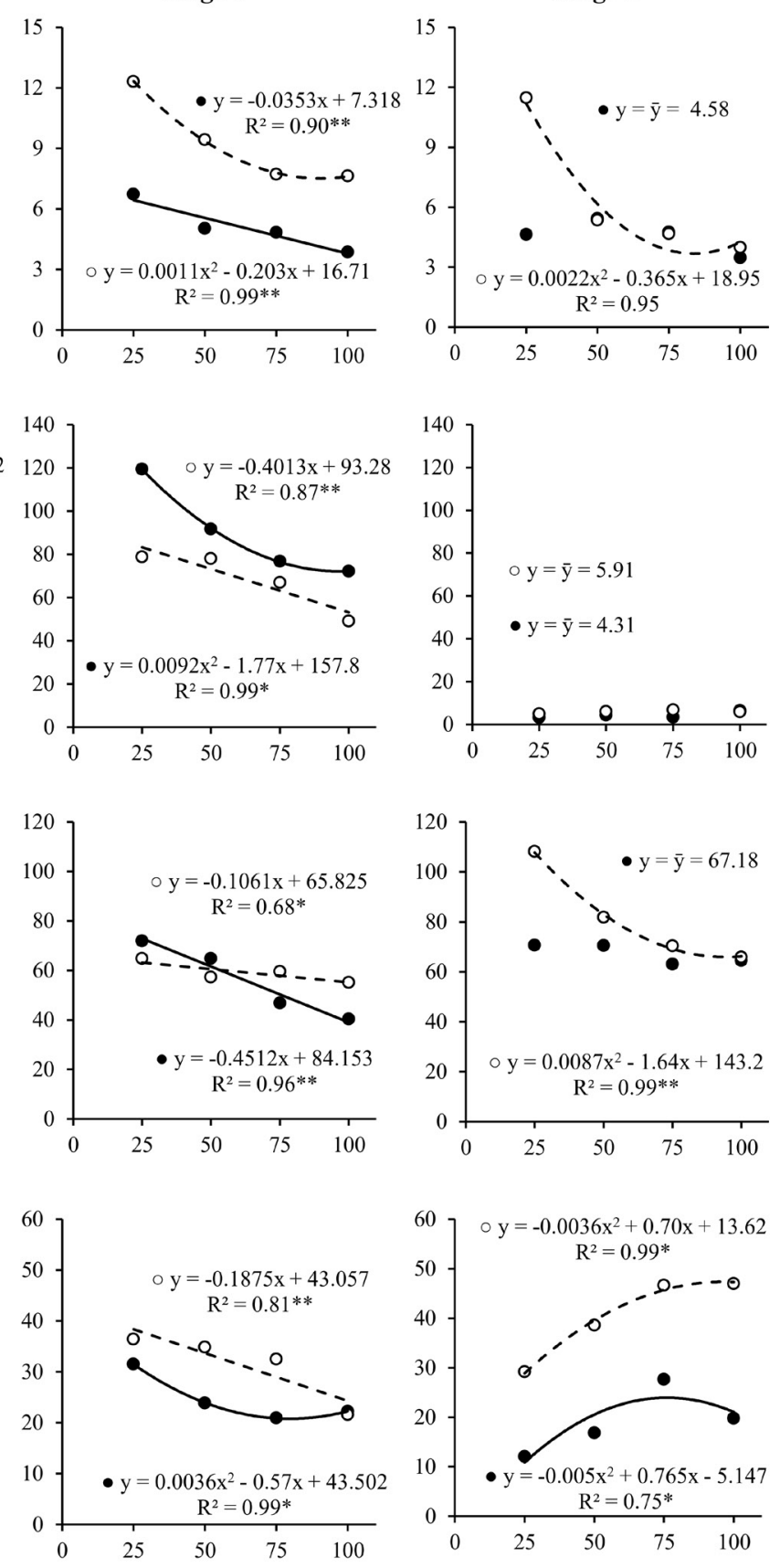

Water availability $(\%)$

Figure 6: Enzyme activity: A) Catalase (CAT) ( $\mu \mathrm{mol} \mathrm{min}^{-1} \mathrm{mg}^{-1}$ protein); B) Ascorbate Peroxidase (APX) ( $\mu \mathrm{mol} \mathrm{min}^{-1}$ $\mathrm{mg}^{-1}$ protein); C - Guaiacol Peroxidase (GPX) ( $\mu \mathrm{mol} \mathrm{min}^{-1} \mathrm{mg}^{-1}$ protein) and D - Superoxide dismutase (SOD) (U SOD $\mathrm{mg}^{-1}$ protein) in cowpea, cultivar 'Carijó', subjected to different water availability levels and temperature regimes in three phenological stages (Stage 1: vegetative, Stage 2: flowering and Stage 3: pod filling). Significant regression coefficient with $p<0.05\left(^{*}\right)$ and $\left.p<0.01{ }^{* *}\right)$. 
For plants that were subjected to reduction in water availability in the vegetative and flowering stages, it can be noted that, in general, the lower the water availability, the greater the specific activity of SOD (first line of defense), as well as the enzymes that act in the second line of defense against oxidative stress (CAT, APX and GPX). The maximum activity of antioxidant enzymes can increase the capacity of cellular protection against oxidative damage, thus contributing to a better tolerance to water deficit and high temperatures (Zandalinas et al., 2018).

On the other hand, plants subjected to water deficit in the pod filling stage showed a lack of synchrony between the enzymes that act on the lines of oxidative defense. With the significant increase in SOD activity, there is a greater accumulation of $\mathrm{H}_{2} \mathrm{O}_{2}$ generated in the dismutation of $\mathrm{O}_{2}{ }^{--}$and, with the reduction in the activity of enzymes that act in the elimination of $\mathrm{H}_{2} \mathrm{O}_{2}$ (as observed for CAT, APX and GPX), there is a possible accumulation of this reactive oxygen species (Barbosa et al., 2014; You; Chan, 2015). The lack of synchrony between the activity of the enzymes evaluated in the pod filling stage may be associated with the phenological age of the evaluated plants, as they were already entering the last stage of their cycle, thus activating the state of senescence, and cell death.

The alterations in enzymatic metabolism recorded in this study demonstrate that the stages of vegetative development and flowering have similar enzymatic behavior. This result may be related to the longer duration of these stages (Figure 2), because one of the main factors that will determine the degree of severity of abiotic stress is the time of exposure to the stress (Ndiso et al., 2016). The longer time of exposure in the vegetative and flowering stages, associated with high intensity of stress, as observed in plants subjected to $25 \%$ water availability, can cause irreversible damage to plants, like the significant reduction in grain production observed in Figure 3A.

Climate change exposes cowpea plants to water deficit and temperature increase, altering their phenology and causing reductions in their growth and yield. Even with these impacts, little is known about the effect of the interaction between these abiotic stresses on the different phenological stages of cowpea. Studies like this indicate that the adoption of irrigation management in the stages in which cowpea is more sensitive to stress will be necessary, since plants will not tolerate the negative effect of water deficit. With the increase in temperature it will be indispensable to know the phenology of the crop, so that one can choose an appropriate planting time, aiming at periods with lower temperatures, especially during the reproductive stage, minimizing the damage caused by temperature and increasing water use efficiency.

\section{CONCLUSIONS}

Low water availability and increase in temperature reduce grain production of cowpea, cv. 'Carijó'. However, the plants were more sensitive to the 4.8 ${ }^{\circ} \mathrm{C}$ increase in air temperature than to water deficit. Application of severe water deficit will only reduce grain production when applied in the vegetative stage, due to the duration of the stress, and in the flowering stage. The combined action of stresses with low water availability and high temperature caused an increase in the activity of enzymes in the antioxidant defense system, evidencing that cowpea plants were under stress, which directly affected their production.

\section{ACKNOWLEDGEMENTS}

The authors would like to thank the Foundation for the Support of Research of the State of Bahia (FAPESB) for funding the doctoral scholarship ( $\left.\mathrm{N}^{\circ} \mathrm{BOL} 0419 / 2017\right)$, the Foundation for the Support of Science and Technology of Pernambuco (FACEPE) (APQ - 0185-5.01/19) and the National Council for Scientific and Technological Development (CNPq) for financial assistance.

\section{REFERENCES}

BARBOSA, M. R. et al. Geração e desintoxicação enzimática de espécies reativas de oxigênio em plantas. Ciência Rural, 44(3):453-460, 2014.

BATISTA, L. S. et al. Calibração de sonda artesanal de uso com TDR para avaliação de umidade de solos. Revista Brasileira de Agricultura Irrigada, 10(2):522-532, 2016.

BERGAMASCHI, H.; BERGONCl, J. I. As plantas e o clima: Princípios e aplicações. Guaíba: Agrolivros, 2017. 352p.

BORELLA, J. et al. Differential response to water stress in two tropical common bean cultivars. Revista Brasileira de Ciências Agrárias, 12(3):316-324, 2017.

CAKMAK, I.; HORST, W. J. Effect of aluminium on lipid peroxidation, superoxide dismutase, catalase, and peroxidase activities in root tips of soybean (Glycine max). Physiologia Plantarium, 83(3):463-468, 1991.

CARVALHO, M. et al. Evaluating stress responses in cowpea under drought stress. Journal of Plant Physiology, 241(1):1-13, 2019.

CAVALCANTI, F. J. A. de. Recomendações de adubação para o estado de Pernambuco. $2^{\text {a }}$ Apr. 3.ed., Recife: IPA, 2008, 212p. 
FAROOQ, M. et al. Drought stress in grain legumes during reproduction and grain filling. Journal of Agronomy and Crop Science, 203(1):81-102, 2017.

GIANNOPOLITIS, C. N.; RIES, S. K. Superoxide dismutases: I. Occurrence in higher plants. Plant Physiology, 59(2):309314, 1977.

GIRI, A. et al. Heat stress decreases levels of nutrient-uptake and assimilation proteins in tomato roots. Plants, 6(6):1-15, 2017.

GOMES, A. M. G. et al. Breeding elite cowpea [Vigna unguiculata (L.) Walp] varieties for improved food security and income in Africa: Opportunities and challenges. In: EL-ESAWI, M. $\mathrm{H}$. Legume crops - Characterization and breeding for improved food security. Intech Open, p. 626-640, 2019.

HARSANT, J. et al. High temperature stress and its effect on pollen development and morphological components of harvest index in the C3 model grass Brachypodium distachyon. Journal of Experimental Botany, 64(10):2971-2983, 2013.

HASANUZZAMAN, M. et al. Plant tolerance to environmental stress: Role of phytoprotectants. CRC Press, Boca Raton, USA, 2019, 468p.

HASANUZZAMAN, M. et al. Plant response and tolerance to abiotic oxidative stress: Antioxidant defense is a key factor. In: VENKATESWARLU, B. et al. Crop stress and its management: Perspectives and strategies. Springer. Netherlands, p. 261-315, 2012.

HATFIELD, J. L.; PRUEGER, J. H. Temperature extremes: Effect on plant growth and development. Weather and Climate Extremes, 10(1):4-10, 2015.

HAVIR, E. A.; MCHALE, N. A. Biochemical and developmental characterization of multiple forms of catalase in tobacco leaves. Plant Physiology, 84(2):450-455, 1987.

HOFFMANN JUNIOR, L. et al. Resposta de cultivares de feijão à alta temperatura do ar no período reprodutivo. Ciência Rural, 37(6):1543-1548, 2007.

INTERGOVERNMENTAL PANEL ON CLIMATE CHANGE - IPCC. Climate change 2013: The physical science basis. Cambridge: University Press, 2013, 1535p.

JUMRANI, K.; BHATIA, V. S. Impact of combined stress of high temperature and water deficit on growth and seed yield of soybean. Physiology and Molecular Biology of Plants, 24(1):37-50, 2018.

KARIM, T. D. A. et al. Effect of water deficit at different stages of development on the yield components of cowpea (Vigna unguiculata L. Walp) genotypes. African Journal of Biotechnology, 17(9):279-287, 2018.
KOEVOSTS, I. T. et al. Roots withstanding their environment: Exploiting root system architecture responses to abiotic stress to improve crop tolerance. Frontiers in Plant Science, 7(1):1-19, 2016.

KUMAR, R. R. et al. Protection against heat stress in wheat involves change in cell membrane stability, antioxidant enzymes, osmolyte, $\mathrm{H}_{2} \mathrm{O}_{2}$ and transcript of heat shock protein. International Journal of Plant Physiology and Biochemistry, 4(4):83-91, 2012.

KUMAR, M. Impact of climate change on crop yield and role of model for achieving food security. Environmental Monitoring and Assessment, 188(465):1-14, 2016.

MANSOOR, S.; NAQVI, F. N. Effect of heat stress on lipid peroxidation and antioxidant enzymes in mung bean (Vigna radiata $\mathrm{L}$ ) seedlings. African Journal of Biotechnology, 12(21):3196-3203, 2013.

MELO, A. S. de. et al. Photosynthetic efficiency and production of cowpea cultivars under deficit irrigation. Revista Ambiente \& Água, 13(5):1-8, 2018.

MERWAD, A. R. M. A.; DESOKY, E. S. M.; RADY, M. M. Response of water deficit-stressed Vigna unguiculata performances to silicon, proline or methionine foliar application. Scientia Horticulturae, 228(1):132-144, 2018.

MURGA-ORRILLO, H. et al. Evapotranspiração e coeficiente de cultivo do feijão-caupi cultivado em solo do cerrado submetido à cobertura morta. Irriga, 21(1):172-187, 2016.

NAKANO, Y.; ASADA, K. Hydrogen peroxide is scavenged by ascorbate specific peroxidase in spinach chloroplast. Plant Cell Physiology, 22(5):867-880, 1981.

NEMESKÉRI, E.; HELYES, L. Physiological responses of selected vegetable crop species to water stress. Agronomy, 9(8):119, 2019.

NDISO, J. B. et al. Effect of drought stress on canopy temperature, growth and yield performance of cowpea varieties. International Journal of Plant \& Soil Science, 9(3):1-12, 2016.

OLIVEIRA, L. F. C de. et al. Conhecendo a fenologia do feijoeiro e seus aspectos fitotécnicos. Brasília: Embrapa Arroz e Feijão, 2018, 59p.

SCHMIDT, D. et al. Caracterização fenológica, filocrono e requerimento térmico de tomateiro italiano em dois ciclos de cultivo. Horticultura Brasileira, 35(1):89-96, 2017.

SEHGAL, A. et al. Drought or/and heat-stress effects on seed filling in food crops: Impacts on functional biochemistry, seed yields, and nutritional quality. Frontiers Plant Science, 9(1):1-19, 2018. 
SILVA, S. et al. Uso econômico da água para o feijão caupi na região do sertão alagoano. Revista Brasileira de Agrotecnologia, 9(1):7-13, 2019.

SILVA, D. A. et al. Influence of high temperature on the reproductive biology of dry edible bean (Phaseolus vulgaris L.). Scientia Agricola, 77(3):e20180233, 2020.
YOU, J.; CHAN, Z. ROS regulation during abiotic stress responses in crop plants. Frontiers Plant Science, 6(1):1-15, 2015.

ZANDALINAS, S. I. et al. Plant adaptations to the combination of drought and high temperatures. Physiologia Plantarium, 162(1):2-12, 2018. 